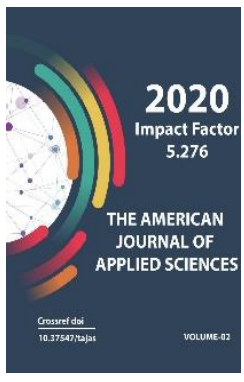

Journal Website: http://usajournalshub.c om/index,php/tajas

Copyright: Original content from this work may be used under the terms of the creative commons attributes 4.0 licence.

\section{Some Solutions To The Desert Process In The Current Amudarya Delta}

Khursanov D.B.

Ph.D., Samarkand State University, Uzbekistan

Joniev O.T.

Assistant Of Navoi State Pedagogical Institute, Uzbekistan

\title{
ABSTRACT
}

This article describes the process of desertification in the current delta of the Amudarya, the factors affecting it, some solutions to them.

\section{KEYWORDS}

Delta, desertification, ecosystem, hydromorph, structure, geosystem, elementary landscape, phytomeleration

\section{INTRODUCTION}

Desertification is a process that occurs as a result of environmental ecosystems, declining fertility, degradation of fertile lands, climate aridity and other anthropogenic factors. Currently, the desertification process is taking place in a very short period of time, leading to changes in all types of geosystems, including natural and anthropogenic landscape complexes. 


\section{MATERIALS AND METHODS}

The current delta of the Amudarya stretches from the city of Nukus to the 1961 border of the Aral Sea. With an area of 19,000 km2, it is the most impressive area where desertification is accelerating. Several factors that contribute to the desertification process in the delta can be listed. In particular, the first factor is the drying up of the Aral Sea, and the second is the change in the level of mineralization of water as a result of the use of river water for irrigation in the upper reaches of the Amudarya. In particular, the dried part of the sea disperses large amounts of salts along with dust into the delta through the deflation process. As a result, salinization, dynamic landscape changes and desertification are observed in the delta arable lands.

Until 1961, the natural geographical conditions in the present-day Amudarya delta were linked to the water level of the Amudarya and the level of the Aral Sea, and the climate was much wetter than it is today. With the change of the climate of the region, hydromorphic soils became free from the influence of groundwater and became automorphic soils. Groundwater is deepening, the process of gradual desertification and salinization is intensifying, and the area of meadow-grass, meadow-desert soils and salt marshes is expanding. As a result, the vegetation cover (Aeluropus littoralis), reeds (Phragmites australis), reeds (Typha angustifolia, $\mathrm{T}$. latifolia) is thinning, desert-specific black saxaul (Haloxylon aphyllum), willow (Tamarix hispida), buckthorn (Halostach) (Halocnemum strobilaceum (Pall)) is being replaced by plant formations.

In the irrigated areas of the current delta of the Amudarya, there are changes in the landscape, the deterioration of land reclamation. This is because the collectors in the area do not drain the groundwater well due to the different slope of some parts of the delta. As a result, salts accumulate in the lowlands, leading to the formation of swamps.

A.K. Urazbaev divided the present-day delta of the Amudarya into small deltas of different ages, including the Amudarya River in the north, the Kazakdarya, Raushan, Kipchakdarya, Akboshli, and the southern part of the Erkindarya in the Amudarya, Uldarya, Kiyatjargan, Shortombay, and QizketkenChimbay.

It should be noted that each network separated from the Amudarya formed its own sub-delta, and the internal structure of each sub-delta is closely related to the energy of this network. Therefore, each small delta differs from other small deltas by its area and internal structure.

In the eastern part of the Qizketken-Chimbay small delta, intermountain lowlands cover a large area. The soil is strong and the depth of very strongly saline groundwater is 1-2 meters. Therefore, the yield of agricultural crops is not high. It is therefore advisable to use this part of the delta as pasture for livestock development.

\section{RESULTS AND DISCUSSIONS}

The Kohnadarya-Kazakdarya, Kipchakdarya and Akboshli small deltas are located in nonirrigated areas and are connected to the 1961 border of the Aral Sea. The natural geographical processes that take place in these deltas are also associated with the "tree-like" landscape structure of the deltas, while the desertification process in these areas is passive and strong in the lower deltas due to the influence of the Amudarya on the upper parts of the small deltas. 
The Kazakdarya network is radically different from the Kohnadarya network in its internal structure. In the Kazakdarya network, the direction of surface water flow is from west to east, connected to the internal structure of the network. Therefore, depending on the direction of surface water flow, the natural geographical processes from the top to the bottom of the network change in order. As the lowlands at the bottom of the network are connected to the dry part of the Aral Sea, the salinization process is more strongly developed in the lower part of the network than in the upper part. At the same time, the lowlands in the lower reaches of the Kazakdarya network are bordered by Lake Jiltirbas, which currently exists at the expense of sewage. Therefore, there are landscape species in the hydromorph group in this area. In short, the Kazakdarya network differs from the natural geographical processes that take place in the Kohnadarya network by its natural geographical processes, at least in part. This difference is noticeable in the relatively weak development of the desertification process in the Kazakh river network.

The eluvial elementary landscape in the Kohnadarya network is located in a large area due to the fact that the river basins occupy a large area. There are differences in the geochemical composition of the eluvial elementary landscapes located in the initial part of the Kuhnadarya network and the eluvial elementary landscapes located in the middle and lower parts of the network. Due to the strong influence of the dried part of the Aral Sea on the eluvial elementary landscape in the lower part of the Kohnadarya network, the salinization process takes place in these landscapes due to external salts. In general, there are also regional differences in the eluvial elementary landscape located in the highlands of the Kohnadarya network, which is due, on the one hand, to the lithological composition of the region and, on the other hand, to the proximity of the Aral Sea. Therefore, although the depth of groundwater in all areas of the eluvial elementary landscape is less than $7 \mathrm{~m}$, the eluvial elementary landscape at the top of the Kohnadarya network differs in its geochemical composition from the eluvial elementary landscape at the bottom. These differences are mainly evident in the amounts of salts in the soils.

The natural geographical processes that take place in these deltas are also associated with the "tree-like" landscape structure of the deltas, where the desertification is slow in these areas and strong in the lower deltas due to the influence of the Amudarya on the upper deltas.

Thus, the three groups of relief of the current delta of the Amudarya (river basin, slopes of the river plateaus, inter-river lowlands) have a direct impact on the geoecological situation in the delta, the acceleration of desertification. The soil cover of the river basins differs from the inter-river basins in its salinity and groundwater level. In short, it is expedient to take into account the magnitude of the role of riparian elevations, slope elevation slopes, and interstitial lowlands associated with surface water flow in the deterioration of the geoecological situation in deltas.

\section{CONCLUSION}

In our opinion, it is expedient to take the following measures to eliminate the severity of the Aral Sea problem and prevent desertification: - When increasing the vegetation cover in small deltas by phytomelioration, it is necessary to take into account the natural geographical processes occurring in the upper, middle and lower parts 
of the deltas, ie to pay attention to the fact that each plant species gives positive results only if planted in appropriate ecological conditions; Along with the water consumption of the Amudarya, the structure of the delta relief plays an important role in the construction of artificial reservoirs. If we analyze the relief of the current delta of the Amudarya, the largest lowlands are around Lake Sudoche, between the heights of the Kohnadarya and Amudarya, between the heights of the Akbashli and the heights of the Amudarya, between the lower part of the Erkindarya small delta and the Amudarya delta. taking into account the occurrence in the area adjacent to the lake and elsewhere; In the organization of artificial water basins, first of all, along with the water consumption of the Amudarya, the size of the lowest point and the height of the surrounding basin play a special role, ie the greater the difference between the lowest area and the highest area, pay attention to the larger the capacity and area; - Development of cost-effective ways to use water resources, the introduction of the issue of payment for the use of water in the transition to market relations; -After the harvest of loose crops, nothing is planted on the fallow lands and the soil, which is not protected from the heat of summer, heats up and prevents strong salinization as a result of very high evaporation; - In the design of agricultural crops to take into account the mechanical composition of the soil, the delta heights of the delta, the slopes of the delta heights, inter-river lowlands.

\section{REFERENCES}

1. Abbasov S.B. Kyzylkum landscapes and their geoecological aspects. Geogr. Ph.D. written diss to obtain an academic degree. abstracts. -T .; 2007.-39.b.
2. Rafikov V.A. Sostoyanie Aralskogo morya i Priaralya until 2020. - T : OOO "Munis desion group", 2014. - $111 \mathrm{p}$.

3. Urazbaev A.K. Sistemnaya organizatsiya prirodno-meliorativnyx usloviy sovremennoy delty Amudari. // Author's abstract dissertation. on soisk.uch.stepeni dokt.geogr.nauk. - T .: 2002. -48 p.

4. Khursanov D.B. The structure and stratification of the landscapes of the modern delta of the Amudarya. // Geog. fan. Ph.D. diss. avtoref. - Samarkand; 2019. - Б. 40.

5. Khursanov D.B., Urazbayev A.K. The Role of Relief Structure in the Stratification of the Landscapes of the Current Delta of Amudarya. Bulletin of Pure and Applied Sciences 'Section F - Geology'. India. 2020.

6. Muhamadjonovna, S. D. (2020). The key concepts of forming sociolinguistic competence of future English language specialists. Asian Journal of Multidimensional Research (AJMR), 9(5), 118-121.

7. Muhamadjonovna, S. D. (2020). The development of sociolinguistic competence of future English language teachers through computer technologies 